\title{
Colony size, sex ratio and cohabitation in roosts of Phyllostomus hastatus (Pallas) (Chiroptera: Phyllostomidae)
}

\author{
Costa, LM.*, Lourenço, EC., Esbérard, CEL. and Silva, RM. \\ Laboratório de Diversidade de Morcegos, Instituto de Biologia - IB, \\ Universidade Federal Rural do Rio de Janeiro - UFRRJ, Km 47 da antiga estrada Rio-São Paulo, \\ CP 74507, CEP 23890-000, Seropédica, RJ, Brazil \\ *e-mail: lucianamcosta@yahoo.com.br \\ Received February 16, 2009 - Accepted January 12, 2010 - Distributed November 30, 2010
}

(With 4 figures)

\begin{abstract}
Phyllostomus hastatus bat is species broadly distributed over the Neotropical region, which uses as diurnal roosts caves, hollow trees, palm leaves and human buildings. Thirteen diurnal roosts of $P$. hastatus were analysed from 1990 to 2009 in several localities of Rio de Janeiro State, regarding environment (rural, urban or protected area), type of roost (hollow tree, basement or roof), sex ratio and cohabitation. A nocturnal roost was also analysed. Sex ratio of $P$. hastatus varied considerably among roosts what may be explained by the fact this species can roost alone, in couples, in harems or in groups of bachelor males. Phyllostomus hastatus was observed in cohabitation with three other species: Molossus rufus, Molossus molossus and Myotis nigricans. Due to the frequency of cohabitation observed between P. hastatus and species of the genus Molossus, one or more advantages for the members of this association may be expected. The simultaneous usage of a feeding roost by a group of bachelor males is unknown information in the literature, and may suggest that this kind of group may interact with each other even when away from their diurnal roosts.
\end{abstract}

Keywords: diurnal roost, nocturnal roosts, Southeastern Brazil.

\section{Tamanho da colônia, proporção sexual e coabitação em refúgios de Phyllostomus hastatus (Pallas) (Chiroptera: Phyllostomidae)}

\begin{abstract}
Resumo
Phyllostomus hastatus é uma espécie de morcego amplamente distribuída na região Neotropical, que utiliza como abrigo diurno cavernas, ocos de árvores, folhas de palmeiras e construções humanas. Treze abrigos diurnos de P. hastatus foram analisados entre 1990 e 2009, em diferentes localidades do Estado do Rio de Janeiro, quanto ao ambiente (rural, urbano ou unidade de conservação), tipo de refúgio (oco de árvore, porão ou telhado), proporção sexual e coabitação. Um abrigo noturno também foi analisado. A proporção sexual de $P$. hastatus nos agrupamentos estudados variou consideravelmente entre os abrigos, e isto pode ser explicado pelo fato desta espécie refugiar-se isoladamente, em casais, como haréns e em grupos de machos solteiros. Phyllostomus hastatus foi observado em coabitação com Molossus rufus, $M$. molossus e Myotis nigricans. Dada a frequência de observação da coabitação entre $P$. hastatus e espécies do gênero Molossus, espera-se uma ou mais vantagens para os integrantes desta associação. O uso de abrigo noturno por um grupo de machos solteiros é fato ainda inédito e pode sugerir que machos solteiros possam estar interagindo mesmo fora de seus abrigos diurnos.
\end{abstract}

Palavras-chave: abrigo diurno, abrigo noturno, Sudeste do Brasil.

\section{Introduction}

Phyllostomus hastatus (Pallas, 1767) is a bat species broadly distributed over the Neotropical region, which occurs from southern Belize to northern Argentina (Santos et al., 2003). This species occurs in 19 Brazilian states, comprising all the country's biomes (Nogueira et al., 2007). Phyllostomus hastatus is considered a big sized species (>100 g), being the second heaviest species in Neotropical Region and has an omnivorous diet ( $\mathrm{McNab}$ and Morrison, 1963; Gardner, 1977; Simmons and Voss,

1998; LaVal and Rodríguez-Herrera, 2002; Santos et al., 2003; Oprea et al., 2006). Individuals of this species use as diurnal roosts caves, hollow trees, palm leaves and human buildings (Peracchi et al., 1984; Patterson, 1992; Pinto-da-Rocha, 1995; Ascorra et al., 1996; Trajano and Gimenez, 1998; Bredt et al., 1999; Esbérard et al., 1999; Esbérard, 2001; Esbérard et al., 2005) and may be found sharing huge roosts with over 15 different bat species (e.g. Tuttle, 1970; Ochoa, 1985; Bredt et al., 1999). In 
their diurnal roosts couples, harems of over 100 females, groups of bachelor males and sole individuals may be found (McCraken and Bradbury, 1981; McCracken and Wilkinson, 2000; Esbérard, 2001).

The roosts and their analysis are important to estimate adaptability to the environment and structures used, to make an estimate of group size, cohabiting species and what interspecific relations they establish. Despite its broad geographical distribution in Brazil, there are few accounts on $P$. hastatus roosts.

The objective of the present study was to record the composition of groups of $P$. hastatus inside diurnal roosts and in one nocturnal roost, relating the environment type (rural, urban or protected area), the structure used (hollow tree, basement or roof), sex ratio, cohabitation and a variation of the number of bats in a roof sampled at monthly intervals are presented.

\section{Material and Methods}

Thirteen diurnal roosts and one nocturnal roost of $P$. hastatus were studied in several localities of Rio de Janeiro state from 1990 to 2009 (Figure 1). Diurnal roost sites were informed by local inhabitants $(\mathrm{N}=5)$ or through active searching by the researchers during bat inventories
$(\mathrm{N}=8)$. In one roost located at Reserva Biológica Poço das Antas monthly samplings were performed from November 2000 to October 2001 [see Esbérard (2002) for details]. A roost located in a hollowed tree in Fazenda da Barra was sampled seven times between November 1998 and February 2003 [see Esbérard et al. (2003), for details]. Six more roosts were visited more than once (2-3 times), including visits at night.

For each roost the following aspects were considered: environment type (rural, urban or protected area), height of the roost and the accesses, type (hollow tree, basement or roof), sex ratio of male and female adults of $P$. hastatus, and whether there was cohabitation with other bat species with or without interspecific contact. When cohabitation was detected, nocturnal observations were carried out to determine whether animals of different species used the same exiting access of the roost.

We calculated a simple linear regression between roosts area and the number of $P$. hastatus found.

The animals were captured during daytime (usually from 10:00 AM to 12:00 PM) by hand or with adapted pinchers, by nylon entomologic nets or during the night in mist nets set on the access, inside these roosts or using a modified Davis trap functioning all night long (see Esbérard, 2002, 2003). Specimens captured had their sex

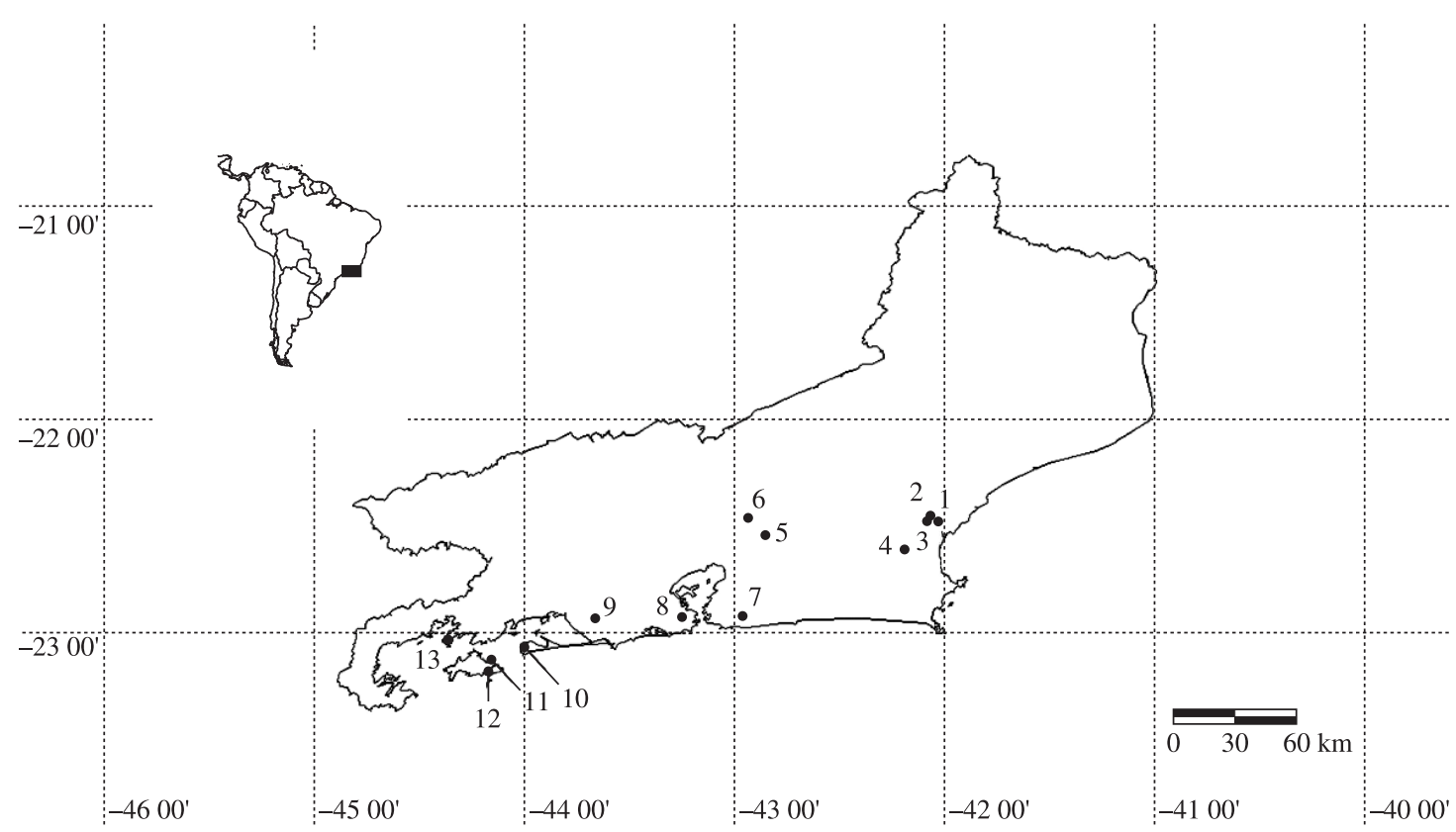

Figure 1. Location of the roosts of Phyllostomus hastatus analysed from 1998 to 2009 in Rio de Janeiro State. 1) Fazenda da

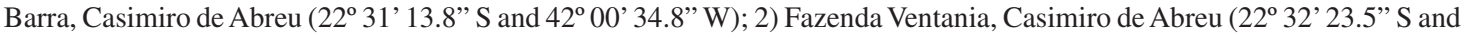

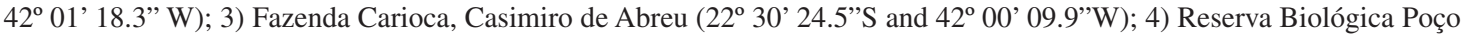

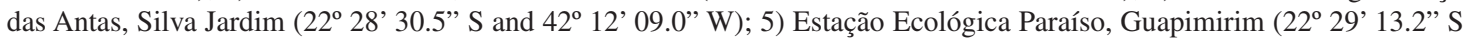

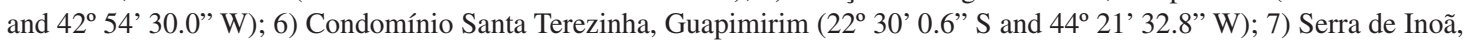

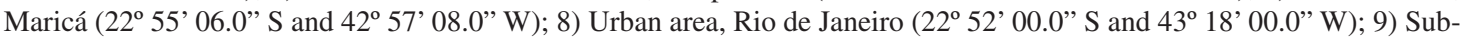

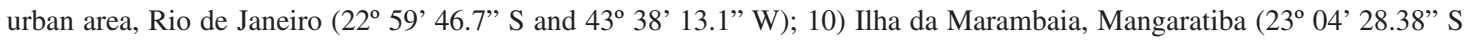

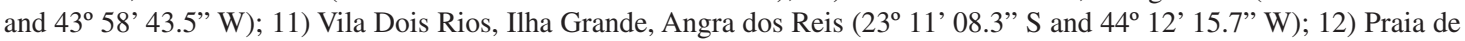

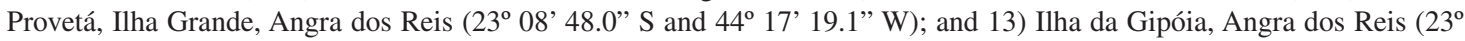
02 ' 34.4" S and $\left.44^{\circ} 21^{\prime} 32.8^{\prime \prime} \mathrm{W}\right)$. 
determined, were marked with plastic necklaces with coloured cylinders (Esbérard and Daemon, 1999) and were released at the same site. A single nocturnal roost was continuously observed from November 2006 until March 2009, and the usage of this structure was inferred through fecal spots on the walls of a building and food remains. This roost (12 $\mathrm{m}$ high) was located in a gap over the stairs of the Biology Institute (Instituto de Biologia) of Universidade Federal Rural do Rio de Janeiro, Seropédica municipality, and it has been intermittently used by $P$. hastatus for more than ten years (personal information from workers). A sampling night was accomplished in this place (December 2007, see Silva et al., 2007), with mist nets set next to the perching sites.

\section{Results and Discussion}

The diurnal roosts of P. hastatus observed in Rio de Janeiro state were located in conservation units, urban and rural environments, comprising hollow trees and human buildings (Table 1). All roofs used by bats were in one storey houses (3-6 m high), except one, in a second floor (12 $\mathrm{m}$ high).

Phyllostomus hastatus seems to be a species that is well adapted to human environments, where it can use several structures as roosts (Tuttle, 1976; Peracchi et al., 1984; Patterson, 1992; Esbérard et al., 1999; Esbérard, 2001; Santos et al., 2003). The roofs used as roosts in Rio de Janeiro state varied in size (from 40 to $150 \mathrm{~m}^{2}$ ) and the area had no relation to the maximum number of bats per colony $(\mathrm{N}=7, \mathrm{r}=0.324, \mathrm{p}=0.479, \mathrm{~F}=0.586)$.

Variation in the total number of bats using the structure in each night of sampling was observed in three roosts analysed more frequently. In the Reserva Biológica Poço das Antas, a roost sampled in a monthly interval, the number of bats sharing the roost (one roof) varied from 0 to 29 bats ( $11.33 \pm 9.14$ bats), with females predominating every month, except in April, when a sole male was captured. Bats of both sexes were absent in March and May (Figure 2). In Fazenda da Barra in a hollow tree sampled seven times ( $7.60 \pm 4.10$ bats), females predominated in five samples and males are absent in two months and no bats were observed in two samples (in April and May). In one roof located at Ilha da Gipóia three samples were performed with males predominant in all times (June, September and October) and four females present only in September. Phyllostomus hastatus seems to be absent or in reduced number immediately after the breeding season that probably lasts from July to February in this latitude (see Santos et al., 2003). This period of lesser occupation in the roost coincides with the period that Molossus rufus (E. Geoffroy, 1840) was also absent in one of the roost analysed (see Esbérard, 2002). This species of bat seems to use frequently more than one roost as judged to the small number of recaptured animals observed in the returning samplings. From a total of 136 captures of $P$. hastatus in the Reserva Biológica Poço das Antas, only 35 were recaptures and no recaptures were observed in the hollow tree in Fazenda da Barra were analyzed.

Sex ratio between males and females in each roost varied from 1:0.04 to 1:7.7. This variation may be explained by the fact this species may roost in couples, harems (Figure 3) or groups of bachelor males (Figure 4) (McCraken and Bradbury, 1981; McCracken and Wilkinson, 2000). The sex ratio of 1:0.95 obtained when considering together all diurnal roosts without recaptures (190 males and 179 females) assumes that an equal proportion of sexes will be encountered in this species.

Roosting bats assume two postures. In most cases bat were hanging from the wood structure, with contact of the dorsum and ventral region with other members of the group and some bats remaining in contact with tiles (Figure 3). The other posture observed was laying on the cement wall, generally with lateral contact with the others

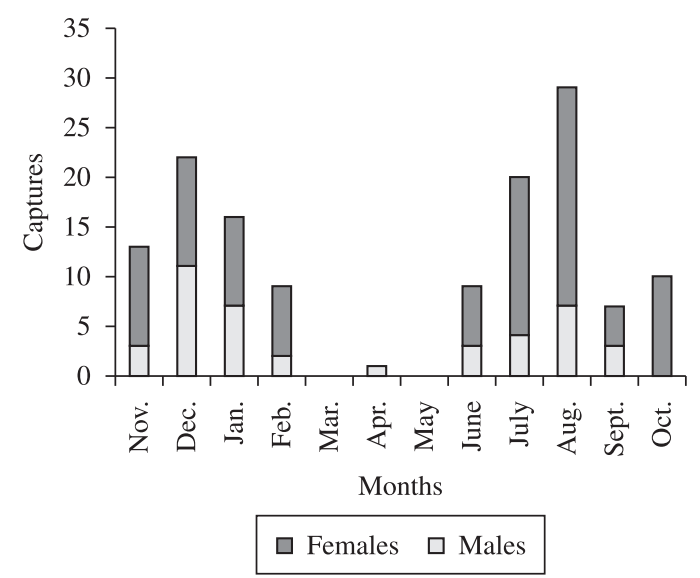

Figure 2. Variation of the captures of males and females of Phyllostomus hastatus in a roost located at Reserva Biológica Poço das Antas, Rio de Janeiro state, sampled at monthly interval from November 2000 to October 2001.

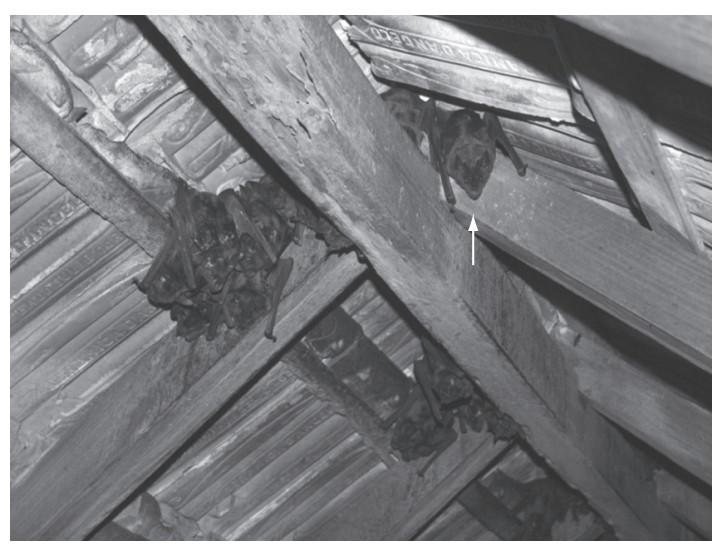

Figure 3. Harem of Phyllostomus hastatus in a roof located in Ilha Grande, Angra dos Reis municipality, Rio de Janeiro state. The arrow points out the male whereas the other individuals are adult females of the same group (Photo by Carl Dick). 

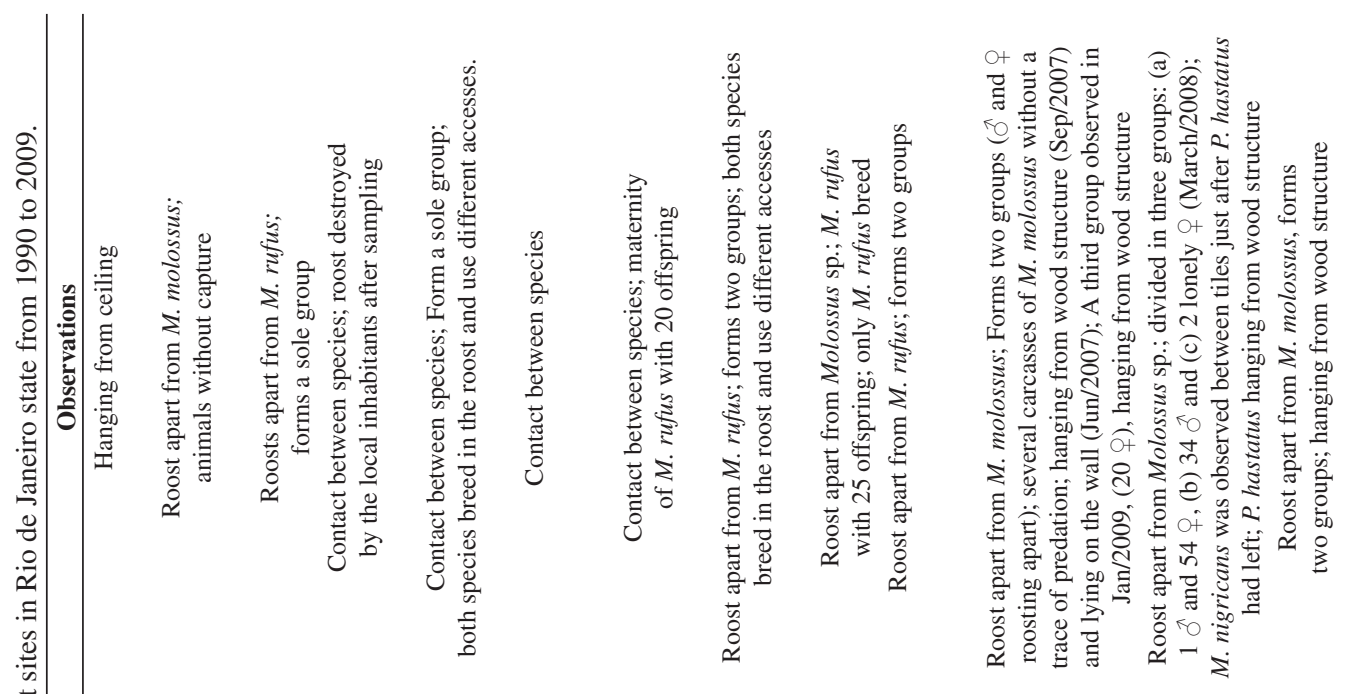

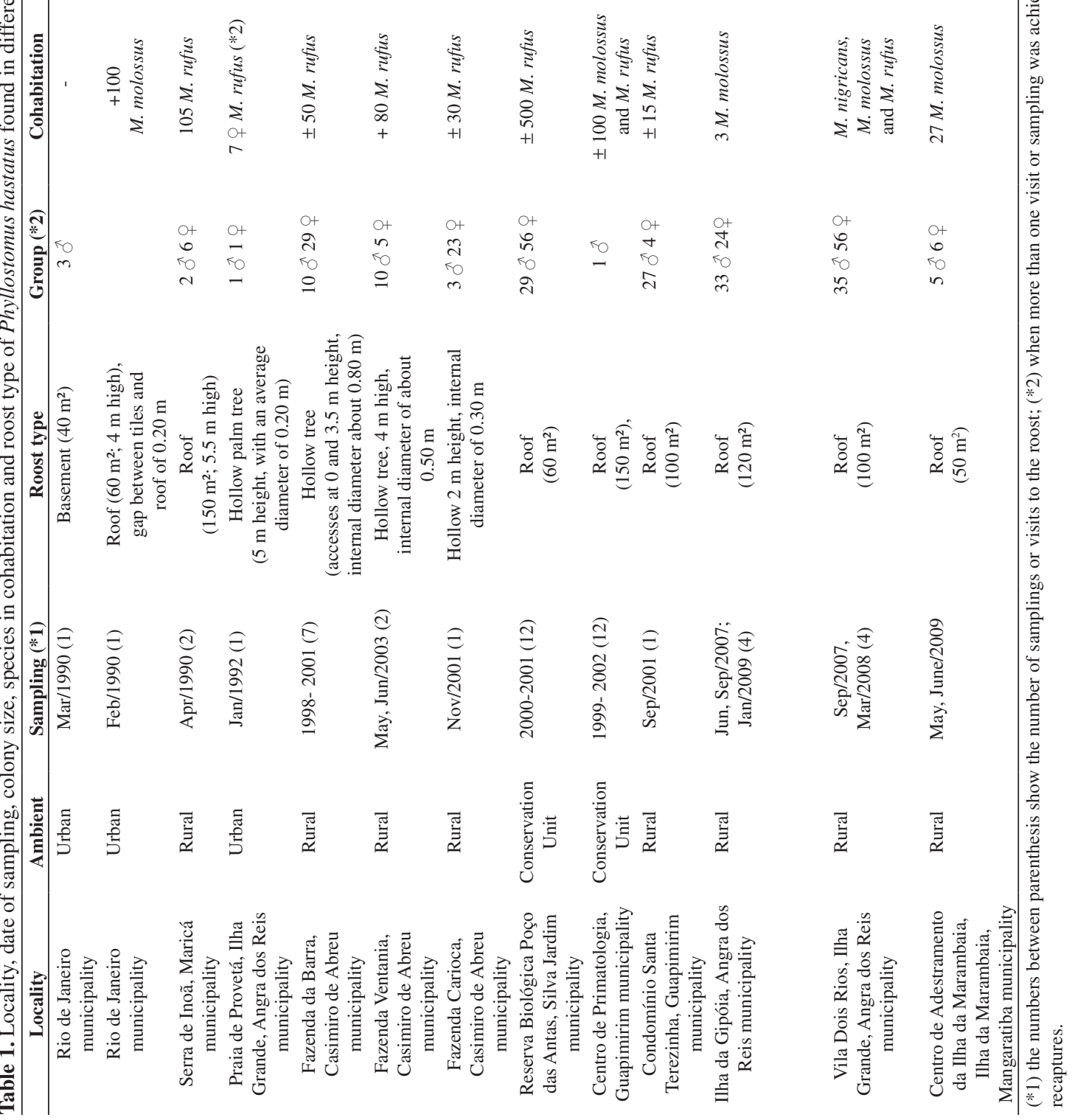




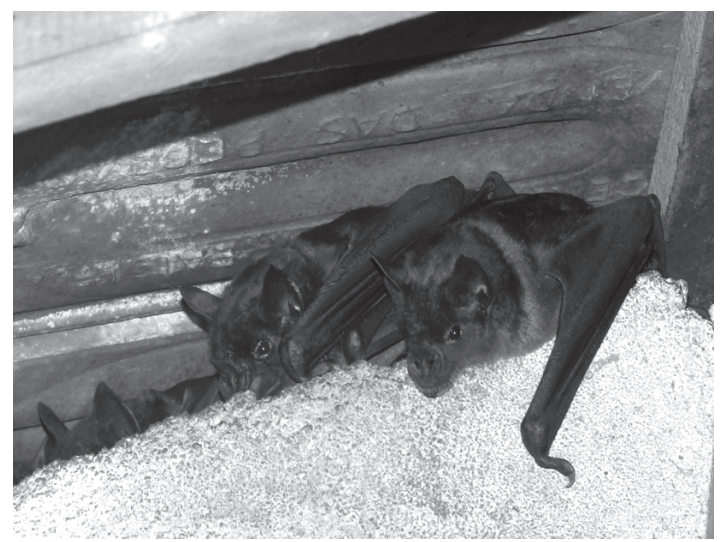

Figure 4. Group of bachelor males of Phyllostomus hastatus in a roof located in Ilha da Gipóia, Angra dos Reis municipality, Rio de Janeiro state (Photo by C.E.L. Esbérard).

bats and the dorsum in contact with the tiles (Figure 4). It is probable that bats adopt each posture depending on the ambient temperature, choosing the maximum proximity to the tiles to obtain heat (see Sazima and Uieda, 1977). The number of groups in each colony probably varies during the day or different seasons of the year since they can also use the contact with other members of the group as a source of heating. Small groups apart from each other inside the roost can be observed on warmer days, generally at midday, and bigger groups can be formed by bats on cooler days (see Sazima and Uieda, 1977).

Phyllostomus hastatus was observed in cohabitation with three species: M. rufus $(\mathrm{N}=8)$, Molossus molossus (Pallas, 1766) $(\mathrm{N}=4)$ and Myotis nigricans (Schinz, 1821) $(\mathrm{N}=1)$. In one roost (roof) these four species were found in cohabitation, whereas in another roost (also a roof), P. hastatus was observed simultaneously cohabiting with $M$. rufus and $M$. molossus, but without any kind of interaction between these species being observed. In all roosts located in hollow trees $(\mathrm{N}=4)$, interspecific contact was observed between $P$. hastatus and $M$. rufus with bats staying side by side. The cohabitation of these three species was first observed by Bredt et al. (1996), but no contact among these species has been described so far. Among the roosts in hollow trees, the smallest had a single access which was used by both species, whereas in the other roosts, specimens of $P$. hastatus and $M$. rufus used different access points. In all roosts (roofs and hollows), $P$. hastatus seems to prefer to use the higher access, except for one roost, where this species uses a small hole beneath the roots $(0.20 \mathrm{~m}$ high), while $M$. rufus used a hole in the first fork (see Esbérard et al., 2003).

In other studies, $P$. hastatus cohabitation was verified without interspecific interactions with Chrotopterus auritus (Petters, 1856), Desmodus rotundus (E. Geoffroy, 1810), Pteronotus davyi (Gray, 1838), Peropteryx macrotis (Wagner, 1843) and Lophostoma silvicolum (d'Orbigny, 1836) (Santos et al., 2003). Although cohabitation with the families Molossidae and Vespertilionidae has only still been infrequently mentioned, this association seems to be common in Rio de Janeiro State, and was observed in 11 out of 13 roosts searched in this study. Due to the frequency of cohabitation observed between $P$. hastatus and species of the genus Molossus, one or more advantages may be expected for participants of this association. Although other studies are needed to test this possibility, a simple increase in bat density may be one possible cause for the association, which would result in an increase of the temperature inside diurnal roosts (Lewis, 1995). Another hypothesis would be a decrease in the predation risk. Molossus rufus has activity very early, being observed departures of the roosts immediately before, during or immediately after the local sunset time (e.g. Marques, 1986; Fenton et al., 1998). Phyllostomus hastatus shows a later activity pattern, preferring to leave the roost after the decreasing light and this behaviour can result in smaller probability to attacks by owls, which would probably prey the first bats leaving roosts (Kramer and Birney, 2001).

Phyllostomus hastatus exhibits omnivorous feeding habits, and may include in its diet other bats (Gardner, 1977; Santos et al., 2003; McNab, 2003). Until now, this predation behaviour is restricted to reports involving smaller species (less than 50g) stuck in nets (Oprea et al., 2006) or offered in captivity, including M. molossus (McNab, 2003). Although the predation of M. molossus and M. rufus by $P$. hastatus was not observed during this study, it is possible that predation occurs under natural conditions and inside roosts, especially involving young molossid bats.

At the access to the only nocturnal roost observed, 16 male specimens were captured, although a maximum of nine individuals were observed using this site simultaneously on the same sampling night. The bats flew to the perching sites (two wall adornments located $6 \mathrm{~m}$ apart) and stayed in contact side by side. The usage of this structure is intermittent, since animals were observed using this site for some consecutive nights and then ignoring it for long periods. The usage of this nocturnal roost probably was restricted to periods when food availability is higher in the proximity and bats choose other perching sites near to the new food source, although it is not possible to locate other structures used as nocturnal roosts by the same group of animals. One or two specimens may be found perched during the day (four occasions between August 2006 and August 2008). Insects and fruit fragments were found on the floor under the perch site, identified as being those of insects (Lepidoptera and Coleoptera), of fig (Ficus spp.), mango (Mangifera indica L.), wax jambu (Syzygium jambolana L. Alston) and jackfruit (Artocarpus integrifolia L.). All these species are so far known to be part of the diet of this species (Gardner, 1977; Fabián et al., 2008, Raices et al., 2008).

The present study is the first record of the use of a nocturnal roost by a group of bachelor males group of $P$. hastatus and may suggest that this kind of group must interact even while at another type of roost. It is known that females of $P$. hastatus fly together or use the same feeding area (Wilkinson and Boughman, 1998) therefore 
it would be interesting to analyse in future studies whether the same happens among bachelor male associations. The frequent cohabitation of $P$. hastatus and Molossus species must be investigated in detail to discover advantages to both species.

Acknowledgements - We thank the Fazenda Carioca Engenharia, Reserva Biológica Poço das Antas, Fazenda da Gipóia, Centro de Adestramento da Ilha da Marambaia, Fazenda Ney Matogrosso, National Geographic Society and Universidade do Estado do Rio de Janeiro for support and sampling funding. We thank Dr. Carl Dick for the picture taken inside the roost on Ilha Grande. Dr. Wilson Uieda made several improvements to the text. Samplings were carried out under a special license from IBAMA (10356-1, obtained in 06/09/2007). We also thank CAPES for the concession of a graduate scholarship to Luciana M. Costa and Elizabete C. Lourenço, and CNPq for the concession of a Research Productivity Fellowship to Carlos E. L. Esbérard (process 301061/2007-6).

\section{References}

ASCORRA, CF., SOLARI, S. and WILSON, DE., 1996. Diversidad y ecologia de los quiropteros em la Pakitza. In WILSON, DE. and SANDOVAL, A., (eds.). Мапи: the biodiversity of Southeastern Peru. Editorial Horizonte. p. 593-612.

BREDT, A., ARAÚJO, FAA., CAETANO-Jr., J., RODRIGUES, MGR., YOSHIZAWA, M., SILVA, MMS., HARMANI, NMS., MASSUNAGA, PNT., BÜRER, SP., PORTO, VAR. and UIEDA, W., 1996. Morcegos em áreas urbanas e rurais: manual de manejo e controle. Brasília, DF: Fundação Nacional de Saúde. 117 p.

BREDT, A., UIEDA, W. and MAGALHÃES, ED., 1999. Morcegos cavernícolas da região do Distrito Federal, centro-oeste do Brasil (Mammalia, Chiroptera). Revista Brasileira de Zoologia, vol. 16, no. 3 , p. 731-770.

ESBÉRARD, CEL., 2001. Infestation of Rhyncopsyllus pullex (Siphonaptera: Tungidae) on Molossus molossus (Chiroptera) at southeastern Brazil. Memórias do Instituto Oswaldo Cruz, vol. 96 , no. 8, p. 1169-1170.

ESBÉRARD, CEL., 2002. Composição de colônia e reprodução de Molossus rufus (E. Geoffroy) (Chiroptera, Molossidae) em um abrigo no sudeste do Brasil. Revista Brasileira de Zoologia, vol. 19 , no. $1-2$, p. $1153-1160$.

ESBÉRARD, C., 2003. Armadilha para retirada de morcegos abrigados em telhado. Chiroptera Neotropical, vol. 9, no. 1-2, p. 164-166.

ESBÉRARD, CEL. and DAEMON, C., 1999. Novo método para marcação de morcegos. Chiroptera Neotropical, vol. 5, no. 1-2, p. 116-117.

ESBÉRARD, CEL., LUZ, EM. and CHAGAS, AS., 1999. Uso de residências por morcegos no Estado do Rio de Janeiro (Mammalia: Chiroptera). Revista Brasileira de Medicina Veterinária, vol. 21, no. 1, p. 17-20.

ESBÉRARD, CEL., MOTTA, AG., OLIVEIRA, DM., AREAS, AF., RODRIGUES, RTV. and BERGALLO, HG., 2003. Observação de fidelidade ao abrigo em Molossus rufus no Estado do Rio de Janeiro, Sudeste do Brasil. Chiroptera Neotropical, vol. 9, no. $1-2$, p. $175-178$.

ESBÉRARD, C., MOTTA, JA. and PERIGRO, C., 2005. Morcegos cavernícolas da Área de Proteção Ambiental Nascentes do Rio
Vermelho, Goiás. Revista Brasileira de Zoociências, vol. 7, no. 2, p. 311-325.

FABIÁN, ME., RUI, AM. and WAECHTER, JL., 2008. Plantas utilizadas como alimento por morcegos (Chiroptera, Phyllostomidae), no Brasil. In REIS, NR., PERACCHI, AL. and SANTOS, GASD., (eds.). Ecologia de morcegos. Technical Books Editora. p. $51-70$.

FENTON, MB., RAUTENBACH, IL., RYDELL, J., ARITA, HT., ORTEGA, J., BOUCHARD, S., HOVORKA, MD., LIM, B., ODGREN, E., PORTFORS, CV., SCULLY, WM., SYME, DM. and VONHOF, MJ., 1998. Emergence, Echolocation, Diet and Foraging Behavior of Molossus ater (Chiroptera: Molossidae). Biotropica, vol. 30, no. 2, p. 314-320.

GARDNER, AL., 1977. Feeding habits. In BAKER, RJ., JONES, JK. and CARTER, DC., (eds.). Biology of bats of the New World Family Phyllostomatidae part II. Local: Texas Tech University Museum. p. 293-350.

KRAMER, KM. and BIRNEY, EC., 2001. Effect of light intensity on activity patterns of Patagonian leaf-eared mice, Phyllotis xanthopygus. Journal of Mammalogy, vol. 82, no. 2, p. 535-544.

LAVAL, RK. and RODRÍGUEZ-HERRERA, B., 2002. Murciélagos de Costa Rica/Costa Rica Bats. Santo Domingo de Heredia: Instituto Nacional de Biodiversidad. 320 p.

LEWIS, SE., 1995. Roost fidelity in bats: a review. Journal of Mammalogy, vol. 76, p. 481-496.

MARQUES, SA., 1986. Activity cycle, feeding and reproduction of Molossus ater (Chiroptera: Molossidae) in Brazil. Boletim do Museu Paraense Emilio Goeldi, vol. 2, no. 2, p. 159-179.

MCCRACKEN, GF. and BRADBURY, JW., 1981. Social organization and kinship in the polygynous bat Phyllostomus hastatus. Behavioral Ecology and Sociobiology, vol. 8, no. 1, p. 11-34.

MCCRACKEN, GF. and WILKINSON, GS., 2000. Bat mating systems. In CRICHTON, EG. and KRUTZSCH, PH., (eds.). Reproductive Biology of Bats. London: Academic Press. p. $321-362$

MCNAB, BK., 2003. Standard energetics of phyllostomid bats: the inadequacies of phylogenetic-contrast analyses. Comparative Biochemistry Physiology, vol. 135A, p. 357-368.

MCNAB, BK. and MORRISON, P., 1963. Observations on bats from Bahia, Brazil. Journal of Mammalogy, vol. 44, p. 21-23.

NOGUEIRA, MR., PERACCHI, AL. and MORATELLI, R., 2007. Subfamília Phyllostominae. In REIS, NR., PERACCHI, AL., PEDRO, WA. and LIMA, IP., (eds.). Morcegos do Brasil. Londrina: Universidade Estadual de Londrina. p. 61-97.

OCHOA, J., 1985. El murciélago carnívoro Chrotopterus auritus (Peters). Natura, vol. 77, p. 30-32.

OPREA, M., VIEIRA, TB., PIMENTA, VT., MENDES, P., BRITO, D., DITCHFIELD, AD., KNEGT, LV. and ESBÉRARD, CEL., 2006. Bat predation by Phyllostomus hastatus. Chiroptera Neotropical, vol. 12, no. 1, p. 255-258

PATTERSON, BD., 1992. Mammals in the Royal Natural History Museum, Stockholm, collected in Brazil and Bolivia by A. M. Olalla during 1934-1938. Fieldiana Zool, new series, vol. 66, p. 1-48.

PERACCHI, AL., RAIMUNDO, SDL. and TANNURE, AM., 1984. Quirópteros do Território Federal do Amapá, Brasil (Mammalia, 
Chiroptera). Arquivos da Universidade Federal Rurual Rio de Janeiro, vol. 7, no. 2, p. 89-100.

PINTO-DA-ROCHA, R., 1995. Sinopse da fauna cavernícola do Brasil (1907-1994). Papeis Avulsos do Departamento de Zoologia da Universidade de São Paulo, vol. 39, no. 6, p. 61-173.

RAÍCES, DSL., PESSÔA, FS., LUZ, JL., JORDÃO-NOGUEIRA, T., ESBÉRARD, CEL. and BERGALLO, HG., 2008. Feeding behaviour of the bat Phyllostomus hastatus (Pallas 1767) in jackfruit Artocarpus heterophyllus Lamarck (Moraceae), in Ilha Grande, Rio de Janeiro State, Brazil. Revista Brasileira de Zoociências, vol. 10 , no. 3 , p. $265-267$

SANTOS, M., AGUIRRE, LF., VÁZQUEZ, LB. and ORTEGA, J., 2003. Phyllostomus hastatus. Mammalian Species, vol. 722, no. 1, p. 1-6.

SAZIMA, I. and UIEDA, W., 1977. O morcego Promops nasutus no sudeste brasileiro (Chiroptera: Molossidae). Ciência e Cultura, vol. 29 , no. 3, p. 312-314.

SILVA, RM., PEIXOTO, G., FRANÇA, D., LOURENÇO, EC., COSTA, LM. and ESBÉRARD, CEL., 2007. Descoloração do pêlo como método de marcação para observações comportamentais. Chiroptera Neotropical, vol. 13, no. 2, p. 323-325.

SIMMONS, NB. and VOSS, RS., 1998. The mammals of Paracou, French Guiana: a Neotropical lowland rainforest fauna. Part 1. Bats. Bulletin of the American Museum of Natural History, vol. 237, p. 1-219.

TRAJANO, E. and GIMENEZ, EA., 1998. Bat community in a cave from eastern Brazil, including a new record of Lionycteris (Phyllostomidae: Glossophaginae). Studies on Neotropical Fauna and Environment, vol. 33, no. 2-3, p. 69-75.

TUTTLE, MD., 1970. Distribution and zoogeography of peruvian bats, with comments on natural history. University of Kansas Science Bulletin, vol. 49, no. 2, p. 45-86.

TUTTLE, MD., 1976. Collecting techniques. In BAKER, RJ., JONES, JK. and CARTER, DC., (eds.). Biology of bats of the new world family Phyllostomidae. Part 1. Special Publications Museum Texas Tech University. p. 71-88.

WILKINSON, GS. and BOUGHMAN, JW., 1998. Social calls coordinate foraging in greater spear-nosed bats. Animal Behaviour, vol. 55 , no. 2, p. 337-350. 
